\title{
The Sodium Effect of Bacillus subtilis Growth on Aspartate
}

\author{
By PATRICIA WHITEMAN, CHERYL MARKS AND ERNST FREESE* \\ Laboratory of Molecular Biology, National Institutes of Health, \\ Department of Health, Education and Welfare, Bethesda, Maryland 20205, U.S.A.
}

(Received 7 December 1979)

\begin{abstract}
aspH mutants of Bacillus subtilis have a constitutive aspartase activity and grow well on aspartate as sole carbon source. aspH aspT mutants, which are deficient in high affinity aspartate transport as a result of the asp $T$ mutation, grow as well as asp $H$ mutants in medium containing high concentrations of aspartate and $\mathrm{Na}^{+}$. This $\mathrm{Na}^{+}$effect is not due to an enhancement of aspartate transport but is the result of increased cellular metabolism. The ability to grow rapidly in sodium aspartate is induced by prior growth in the presence of $\mathrm{Na}^{+}$. In potassium aspartate, the addition of arginine, citrulline, ornithine, $\Delta^{1}$-pyrroline-5carboxylate or proline instead of $\mathrm{Na}^{+}$also allows rapid growth; but in a mutant deficient in ornithine-oxo-acid aminotransferase, only pyrroline-carboxylate or proline can replace $\mathrm{Na}^{+}$. The amino acid pool of cells growing slowly in potassium aspartate contains proline at a low concentration which increases upon addition of proline (but not $\mathrm{Na}^{+}$) to the medium. Thus, $\mathrm{Na}^{+}$addition does not increase the synthesis of proline, but proline or pyrroline-carboxylate acts similarly to $\mathrm{Na}^{+}$either in preventing some inhibitory effect (by aspartate or the accumulating $\mathrm{NH}_{4}{ }^{+}$) or in overcoming some deficiency (e.g. in further proline metabolism).
\end{abstract}

\section{INTRODUCTION}

Whereas wild-type strains of Bacillus subtilis grow only slowly on L-aspartate as sole carbon source until they have adapted to this compound, mutants (aspH) can be isolated which always grow rapidly on aspartate; the asp $H$ mutation renders the strain constitutive in aspartase (Iijima et al., 1977). At high concentrations of sodium aspartate, growth occurs at the same rate irrespective of whether the cells possess a high affinity active aspartate transport system or whether an aspT mutation has eliminated it (Whiteman et al., 1978). The growth on high aspartate concentrations utilizes low affinity but high capacity aspartate transport, the conversion of aspartate to fumarate and ammonia via aspartase, and the subsequent metabolism of fumarate via the citric acid cycle and by gluconeogenesis. It was noticed in the earlier studies in this laboratory that the cultures grew at a much lower rate if sodium aspartate was replaced by potassium aspartate and that addition of $10 \mathrm{~mm}$ or more $\mathrm{Na}^{+}$was optimal for rapid growth on aspartate. In other micro-organisms, growth on L-glutamate requires $\mathrm{Na}^{+}$ions (Frank \& Hopkins, 1969) which apparently are needed to activate glutamate transport, as was reported for Escherichia coli (Halpern et al., 1973; Miner \& Frank, 1974; Tsuchiya et al., 1977) and Mycobacterium phlei (Hirata et al., 1974). In the presence of $\mathrm{Na}^{+}, B$. subtilis aspH mutants, which contain constitutive aspartase, reach the maximal rate of growth only at concentrations $\geqslant 30 \mathrm{~mm}$-aspartate (the maximal rate of active aspartate transport, into isolated membrane vesicles, is obtained at about $6 \mathrm{~mm}$-aspartate). Apparently, up to $30 \mathrm{~mm}$-aspartate the rate of growth is limited by the rate (low affinity) of aspartate transport rather than by that of aspartate catabolism (Whiteman et al., 1978). Since, in the presence of $\mathrm{Na}^{+}$the growth rates increased more 
Table 1. Bacillus subtilis strains

\begin{tabular}{|c|c|c|}
\hline Strain & Genotype* & Origin $\dagger$ \\
\hline 61501 & aspH1 trpC2 & $\begin{array}{l}\text { Spontaneous mutant of } 60002 \text { isolated for rapid growth on } \\
\text { aspartate }\end{array}$ \\
\hline 61507 & aspH1 aspT13 trpC2 & $\begin{array}{l}\text { Spontaneous mutant of } 61501 \text { resistant to DL-threo- } \beta \text {-hydroxy- } \\
\text { aspartate }\end{array}$ \\
\hline 60337 & Amy Hom-2 trpC2 & Ethyl methanesulphonate mutagenesis of 60021 (Amy trpC2) \\
\hline 61702 & Amy aspH1 aspT13 Hom-2 trpC2 & Tf of 60337 by 61507 \\
\hline 60961 & metC7 Pro-2 trpC2 & Nitrosoguanidine treatment of 60015 \\
\hline 60019 & $\operatorname{argO} \operatorname{trp} C 2$ & E. W. Nester \\
\hline 60198 & OrdAI & Ultraviolet mutagenesis of 60009 \\
\hline 61859 & aspH1 aspT13 OrdAI & Tf of 61507 by 60198 \\
\hline
\end{tabular}

* The first letter of a genotype symbol is capitalized if the marker has not yet been mapped.

$\uparrow$ Tf implies transformation of the first strain by DNA of the second strain.

rapidly with the aspartate concentration and reached a higher plateau than in the absence of $\mathrm{Na}^{+}, \mathrm{Na}^{+}$might increase the maximal velocity of aspartate transport. However, it also appeared possible that $\mathrm{Na}^{+}$increased the rate of aspartate metabolism, for example, by preventing the inhibitory effect of high concentrations of aspartate or a compound such as $\mathrm{NH}_{4}{ }^{+}$derived from it. This paper demonstrates that the latter is the case.

\section{METHODS}

Bacteria. The strains used are listed in Table 1. All were derived from the transformable strain 168 of Bacillus subtilis Marburg.

Media and growth conditions. The bacteria were grown in the synthetic salts mixture (S6) described previously (Whiteman et al., 1978). Aspartic acid was used as carbon source, usually at a final concentration of 25 or $50 \mathrm{~mm}$ and adjusted to $\mathrm{pH} 7.0$ with $\mathrm{NaOH}$ or $\mathrm{KOH}$ before use. Growth was followed by the increase in absorbance at $600 \mathrm{~nm}\left(A_{600}\right)$. To express values per cell mass (e.g. in uptake measurements) we have used the 'absorbance mass' $A M_{600}=A_{600} \mathrm{ml}$, which is proportional to the cell mass.

Transformation. DNA of strains 61507 and 60198 was obtained by the method of Saito \& Miura (1963). Portions of the donor DNA were added to recipient bacteria grown in the minimal glucose/citrate medium of Anagnostopoulos \& Spizizen (1961).

Isolation of an aspH aspT Hom strain. DNA of strain 61507 (aspH1 aspT13 trpC2) was added to strain 60337 (Hom-2 trp C2) to obtain an aspT Hom trpC strain which was isolated on $\mathrm{S} 6+$ glucose (25 mM) plates containing $25 \mu \mathrm{g} \mathrm{L}$-homoserine $\mathrm{ml}^{-1}, 25 \mu \mathrm{g}$ L-tryptophan $\mathrm{ml}^{-1}, 0.01 \%$ (w/v) casein hydrolysate and 100

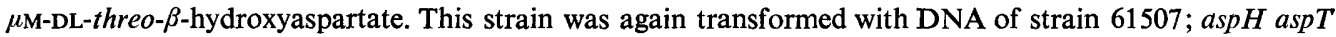
Hom $\operatorname{trpC}$ mutants were isolated by selection in S6 medium containing 25 mM-sodium aspartate, $25 \mu \mathrm{g}$ L-tryptophan $\mathrm{ml}^{-1}$ and $25 \mu \mathrm{g} \mathrm{L}$-homoserine $\mathrm{ml}^{-1}$. Single colonies which grew rapidly on the sodium aspartate were isolated and retested for their resistance to threo-hydroxyaspartate (on S6+glucose) and for their homoserine requirement.

Isolation of an aspH aspT Ord strain. DNA of strain 60198 (OrdA1) was added to strain 61507 (aspH1 aspT13 trpC2). Single colonies which grew rapidly on sodium aspartate $(50 \mathrm{mM})$ as sole carbon source in the absence of added tryptophan were isolated and tested for the Ord property by plating on S6 in which $\mathrm{K}_{2} \mathrm{SO}_{4}(10 \mathrm{~mm})$ replaced $\left(\mathrm{NH}_{4}\right)_{2} \mathrm{SO}_{4}$, and $2 \mathrm{~mm}$-potassium glutamate or $5 \mathrm{~mm}$-ornithine was added as a nitrogen source; $25 \mathrm{~mm}$-glucose was used as carbon source. One such mutant, 61859 (aspH1 aspT13 OrdA1), was used in this work. This mutant was unable to use ornithine as sole nitrogen source but it could use glutamate or proline instead of ammonia.

L-Ornithine:2-oxo-acid aminotransferase assay (EC 2.6.1.13). Bacteria were grown to an $A_{600}$ of 1.0 in S6 containing $50 \mathrm{~mm}$-potassium aspartate with or without $10 \mathrm{mM}-\mathrm{NaCl}$ and with or without $100 \mu \mathrm{g} \mathrm{L}$-ornithine $\mathrm{ml}^{-1}$. Chloramphenicol $\left(100 \mu \mathrm{g} \mathrm{ml}^{-1}\right)$ was then added, and the cells were harvested by centrifuging and washed once with $100 \mathrm{mM}$-Tris/ $\mathrm{HCl} \mathrm{pH} 8.0$ at room temperature. The pellet containing $60 A M_{600}$ units was resuspended in $1 \mathrm{ml}$ of similar buffer containing lysozyme $\left(100 \mu \mathrm{g} \mathrm{ml}^{-1}\right)$. After incubation at $37^{\circ} \mathrm{C}$ for $30 \mathrm{~min}$ the extract was centrifuged for $20 \mathrm{~min}$ at $27000 \mathrm{~g}$ and the supernatant was used for assay.

Ornithine-oxo-acid aminotransferase was assayed by a method based on that of Vogel \& Kopac (1960); the L-glutamic semialdehyde produced in the reaction is spontaneously converted to L- $\Delta^{1}$-pyrroline-5- 
carboxylate which reacts with $o$-aminobenzaldehyde giving a yellow colour (Vogel \& Davis, 1952). The reaction mixture $(1 \mathrm{ml})$ contained $100 \mathrm{~mm}$-Tris $/ \mathrm{HCl} \mathrm{pH} \mathrm{8.0,5} \mathrm{mm}$-L-ornithine, $25 \mu \mathrm{M}$-pyridoxal 5-phosphate, $1 \mathrm{~mm}-o$-aminobenzaldehyde and cell extract containing 0.5 to $1.0 \mathrm{mg}$ protein. After equilibration at room temperature 2-oxoglutarate $(5 \mathrm{~mm})$ was added and the increase in absorbance at $400 \mathrm{~nm}$ was followed.

DL- $\Delta^{1}$-Pyrroline-5-carboxylic acid was prepared from DL- $\Delta^{1}$-pyrroline-5-carboxylate-2,4-dinitrophenylhydrazone. $\mathrm{HCl}$ according to the method given by the manufacturer (Calbiochem) and used to determine its molar absorption coefficient as $21601 \mathrm{~mol}^{-1} \mathrm{~cm}^{-1}$.

L-Aspartate:2-oxoglutarate aminotransferase assay (EC 2.6.1.1). Bacterial extracts were prepared in $50 \mathrm{~mm}$-Tris/HCl buffer $\mathrm{pH} 8.0$ as described for ornithine-oxo-acid aminotransferase. The assay mixture

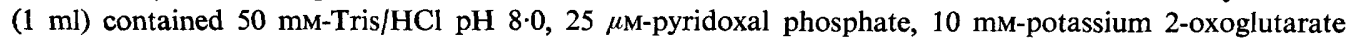
(pH 8), 1.5 international units malate dehydrogenase (Boehringer) and cell extract containing 0.1 to $0.5 \mathrm{mg}$ protein; after equilibration at room temperature for $5 \mathrm{~min}, 0.5 \mathrm{~mm}-\mathrm{NADH}$ (dipotassium salt, prepared just prior to use in $50 \mathrm{~mm}$-Tris/HCl $\mathrm{pH} \mathrm{8.0)}$ ) was added followed by $20 \mathrm{~mm}$-potassium L-aspartate (pH 8). The difference in the rate of decrease of $A_{\mathbf{3 4 0}}$ in the presence and absence of aspartate was used to determine enzyme activity. The effect of $\mathrm{NaCl}(10 \mathrm{~mm})$ on the activity was determined.

Glutamate- $\gamma$-semialdehyde dehydrogenase assay. Attempts were made to demonstrate this enzyme activity in extracts prepared as described above in $100 \mathrm{~mm}$ - Tris/ $\mathrm{HCl} \mathrm{pH} \mathrm{8.0.} \mathrm{Two} \mathrm{methods} \mathrm{were} \mathrm{tried:} \mathrm{(i)} \mathrm{The} \mathrm{assay}$ mixture $(1 \mathrm{ml})$ contained $100 \mathrm{~mm}-\mathrm{Tris} / \mathrm{HCl} \mathrm{pH} 8 \cdot 0,10 \mathrm{~mm}-\mathrm{ATP}$ (dipotassium salt), $5 \mathrm{~mm}-\mathrm{MgCl}_{2}, 0 \cdot 3$ mM-NADPH or NADH (dipotassium salt) and cell extract containing 0.5 to $1.0 \mathrm{mg}$ protein. The decrease in $A_{340}$ was followed and when the rate was constant, $10 \mathrm{~mm}$-potassium L-glutamate (pH 8 ) was added. No effect was seen.

(ii) $o$-Aminobenzaldehyde was used to measure the formation of the product of the reaction, L- $\Delta^{1}-$ pyrroline-5-carboxylate. The assay mixture $(1 \mathrm{ml})$ contained $100 \mathrm{~mm}$ Tris/ $\mathrm{HCl} \mathrm{pH} 8.0$ or $100 \mathrm{~mm}$-sodium phosphate buffer pH 6.6, $10 \mathrm{~mm}$-ATP (dipotassium salt), $5 \mathrm{~mm}-\mathrm{MgCl}_{2}, 10 \mathrm{~mm}-\mathrm{NaCl}$, cell extract containing 0.5 to $1 \mathrm{mg}$ protein and $2 \mathrm{~mm}-o$-aminobenzaldehyde. The absorbance at $440 \mathrm{~nm}$ was followed after the addition of potassium L-glutamate $(10 \mathrm{~mm})$. No reaction was detected, and the same was true when acetyl-CoA (1 mM) replaced ATP. Use of the crude lysozyme extract (without centrifugation) also produced no effect.

Amino acid analysis. Bacteria from an exponentially growing culture were harvested in less than $10 \mathrm{~s}$ on to membrane filters (pore size $0.45 \mu \mathrm{m}$; Millipore) and washed once with an equal volume of warmed S6 medium (without a carbon source). The filters were immediately placed in ice-cold $0 \cdot 3 \mathrm{M}-\mathrm{HClO}_{4}$ plus $0 \cdot 1 \mathrm{mM}$-EDTA ( $1 \mathrm{ml}$ for every $10 A_{600}$ units collected) in a $30 \mathrm{ml}$ Corex centrifuge tube (Corning Glass Works, Corning, N.Y., U.S.A.). (We found this rapid extraction to be essential for reproducible measurements of amino acid pools.) The filters were kept on ice for $5 \mathrm{~min}$ with frequent mixing (on a Vortex mixer). They were then centrifuged at $17000 \mathrm{~g}$ for $10 \mathrm{~min}$ at $4{ }^{\circ} \mathrm{C}$. The supernatant was removed to another cold Corex tube, adjusted to about $\mathrm{pH} 6$ with cold $1 \mathrm{M}-\mathrm{K}_{2} \mathrm{CO}_{3}$, and then centrifuged at $4{ }^{\circ} \mathrm{C}$ for $10 \mathrm{~min}$ at $12000 \mathrm{~g}$. The resulting supernatant was carefully removed to another tube and the $\mathrm{pH}$ was adjusted to $<2$ with ice-cold $1 \mathrm{M}-\mathrm{HCl}$. The extract was rapidly frozen in dry ice/acetone and stored at $-70^{\circ} \mathrm{C}$ until analysed.

Amino acid analysis was performed on a Beckman model 120C amino acid analyser. The acidic and neutral amino acids were determined on a $56 \times 0.9 \mathrm{~cm}$ column of HP AN-90 resin (Hamilton Co., Reno, Nev., U.S.A.) in the $\mathrm{Li}^{+}$form. The basic amino acids were determined on a $26 \times 0.9 \mathrm{~cm}$ column of Aminex A-5 resin (Bio- $\mathrm{Rad}$ ) in the $\mathrm{Na}^{+}$form.

Uptake studies. During exponential growth in $\mathrm{S} 6$ or $\mathrm{S} 6+\mathrm{Na}^{+}$, containing aspartate $(25$ or $50 \mathrm{~mm})$ as carbon source, the bacteria were harvested (usually at $A_{600}=0.5$ unless otherwise noted) by centrifugation ( $12000 \mathrm{~g}$ at room temperature for $5 \mathrm{~min}$ ), washed once with an equal volume of $\mathbf{S} 6$ and resuspended in the same medium. Portions were incubated at $37^{\circ} \mathrm{C}$ in a water bath shaker.

Uptake was initiated by the addition of $\mathrm{L}-\left[\mathrm{U}^{-14} \mathrm{C}\right]$ aspartate $\left(0 \cdot 1 \mu \mathrm{Ci} \mu \mathrm{mol}^{-1}, 3.7 \mathrm{kBq} \mu \mathrm{mol}^{-1}\right)$ to give the desired final concentration (usually $25 \mathrm{~mm}$ and $2.5 \mu \mathrm{Ci} \mathrm{ml} l^{-1}$ ). The radioactivity in samples $(0 \cdot 2 \mathrm{ml})$ was measured as described previously (Whiteman et al., 1978). The initial rates of uptake (nmol $A M_{600}^{-1} \mathrm{~min}^{-1}$ ) were determined from the linear portion of the uptake curves obtained within 2 min (four to six points).

Purification of $\left[{ }^{14} \mathrm{C}\right]$ aspartate $\mathrm{L}-\left[\mathrm{U}-{ }^{14} \mathrm{C}\right]$ Aspartic acid $\left.[125 \mu] ; 203 \mathrm{mCi} \mathrm{mmol}^{-1}, 7 \cdot 5 \mathrm{GBq} \mathrm{mmol}^{-1}\right)$ was applied to an MN300 cellulose plate and run in a solvent system composed of ether/formic acid/water $(7: 2: 1$, by vol. $)$ for $1.5 \mathrm{~h}$ (Myers \& Huang, 1966). The radioactive aspartate was located by autoradiography, eluted with water and freeze-dried. The purified material was added to sodium or potassium aspartate to give $50 \mu \mathrm{Ci}$ $\mathrm{ml}^{-1}$ and $500 \mathrm{~mm}$. The uptake of this aspartate was measured as above and compared with that of unpurified aspartate. 
(a) aspH

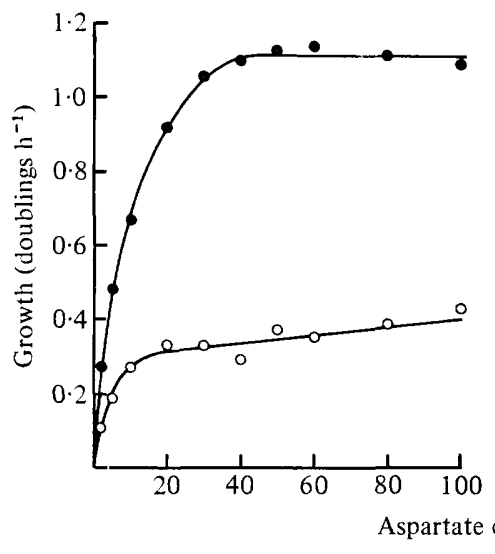

(b) aspH aspT

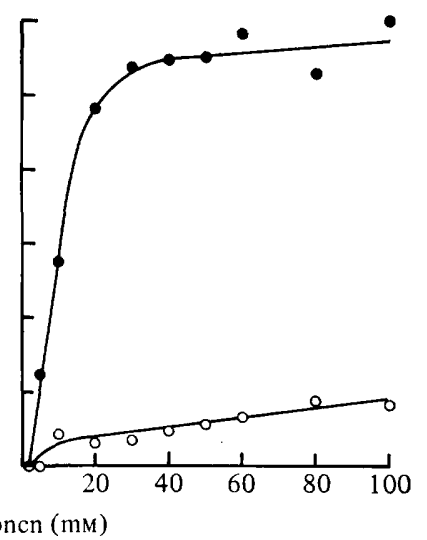

Fig. 1. Aspartate concentration dependence of growth of (a) aspH strain 61501 and (b) aspH aspT strain 61507. Cultures were grown in S6 plus different concentrations of potassium L-aspartate in the presence $(O)$ or absence $(O)$ of $10 \mathrm{~mm}-\mathrm{NaCl}$.

\section{RESULTS}

\section{Effect of sodium on growth}

All strains used contained the aspH mutation which confers on the organism the ability to produce aspartase constitutively (Whiteman et al., 1978). The dependence of the growth of an aspH mutant (61501) on the concentration of aspartate is shown in Fig. 1(a). As has been previously shown (Iijima et al., 1977), the growth rate greatly increased in the presence of $\mathrm{Na}^{+}$(with an optimum of $10 \mathrm{~mm}$ or more). The aspH aspT double mutant lacking the high affinity transport of aspartate grew more slowly than the asp $H$ mutant at low aspartate concentrations but both strains grew at the same rate at high aspartate concentrations exceeding $20 \mathrm{~mm}$; both strains showed the same $\mathrm{Na}^{+}$effect (Fig. 1 b). Thus, growth at high asparate concentrations requires only the low affinity aspartate transport system.

\section{Effect of sodium on aspartate uptake}

To determine whether $\mathrm{Na}^{+}$increased the transport of aspartate or rather exerted its growth stimulatory effect through increased cellular metabolism, the initial rate of aspartate uptake was measured in the presence and absence of $10 \mathrm{mM}-\mathrm{NaCl}$ in both the single and double mutants (Fig. 2). The measurements were made while the cells continued to grow on and to metabolize aspartate. Only a small stimulation by $\mathrm{Na}^{+}$on the initial rate of aspartate uptake was observed which was probably due to an influence of aspartate metabolism on the uptake points obtained within the first 2 min after aspartate addition. But this effect of $\mathrm{Na}^{+}$was clearly much less pronounced than that on growth (Fig. 1). For example, with $25 \mathrm{~mm}$-aspartate, the initial rate of aspartate uptake in the presence of $\mathrm{Na}^{+}$was less than twice that in its absence. In contrast, the rate of growth of the aspH aspT strain was 15 times higher in the presence of $\mathrm{Na}^{+}$than in its absence. Apparently the $\mathrm{Na}^{+}$effect on growth was mainly due to stimulation of cellular metabolism rather than to increased aspartate transport.

Following the initial rapid uptake of aspartate, a slower uptake rate was maintained, as is shown in Fig. 3 for the case of $25 \mathrm{~mm}$-aspartate; it reflects the rate of aspartate metabolism. In the presence of $\mathrm{Na}^{+}$(in cells previously grown on sodium aspartate), these ultimate uptake rates were about $32 \mathrm{nmol} \mathrm{min}{ }^{-1} A M_{600}^{-1}$ for the asp $H$ strain and $23 \mathrm{nmol}$ $\min ^{-1} A M_{600}^{-1}$ for the aspH aspT strain; they were four and eight times higher than in 


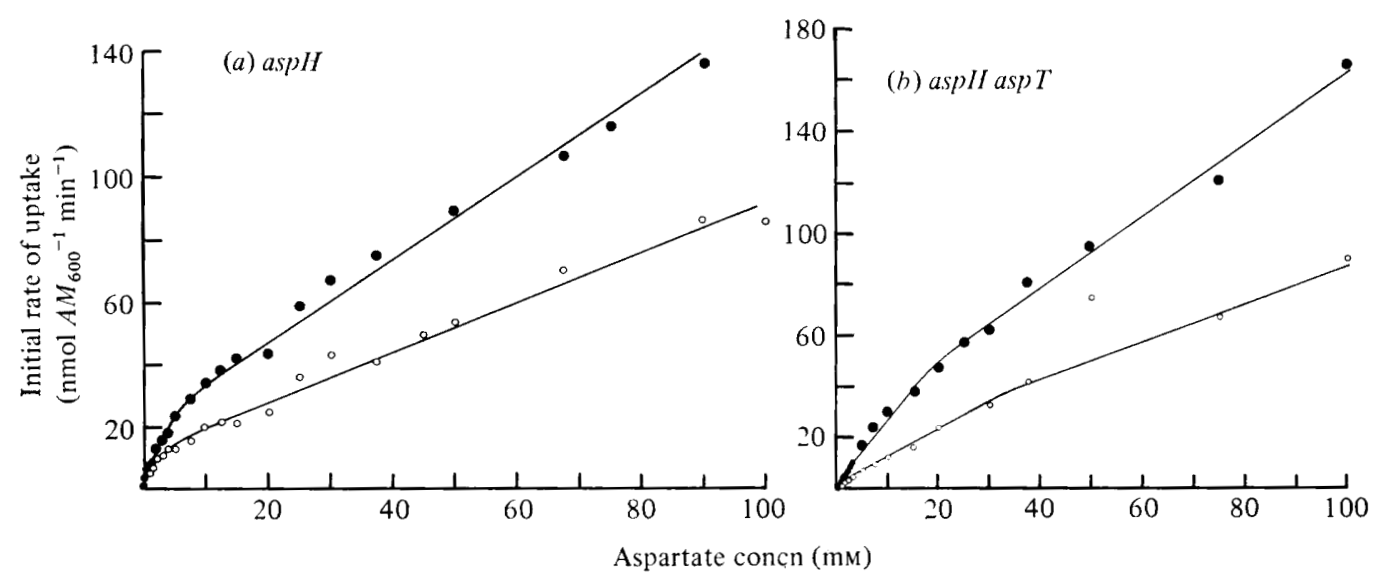

Fig. 2. Aspartate concentration dependence of the initial rate of uptake by (a) asp $H$ strain 61501 and (b) aspH aspT strain 61507. Each strain was grown in $\mathbf{S 6}+50 \mathrm{mM}$-sodium L-aspartate to $A_{600}=0 \cdot 5$, centrifuged, washed and resuspended in S6. Potassium L-[U- $\left.{ }^{14} \mathrm{C}\right]$ aspartate $(0 \cdot 1 \mu \mathrm{Ci}$ $\mu \mathrm{mol}^{-1}$ ) was added to give the final concentration indicated, and the uptake was measured as described in Methods in the presence of $10 \mathrm{~mm}-\mathrm{NaCl}(O)$ or $10 \mathrm{~mm}-\mathrm{KCl}(\bigcirc)$. The initial rate was determined from the points obtained within the first $2 \mathrm{~min}$.

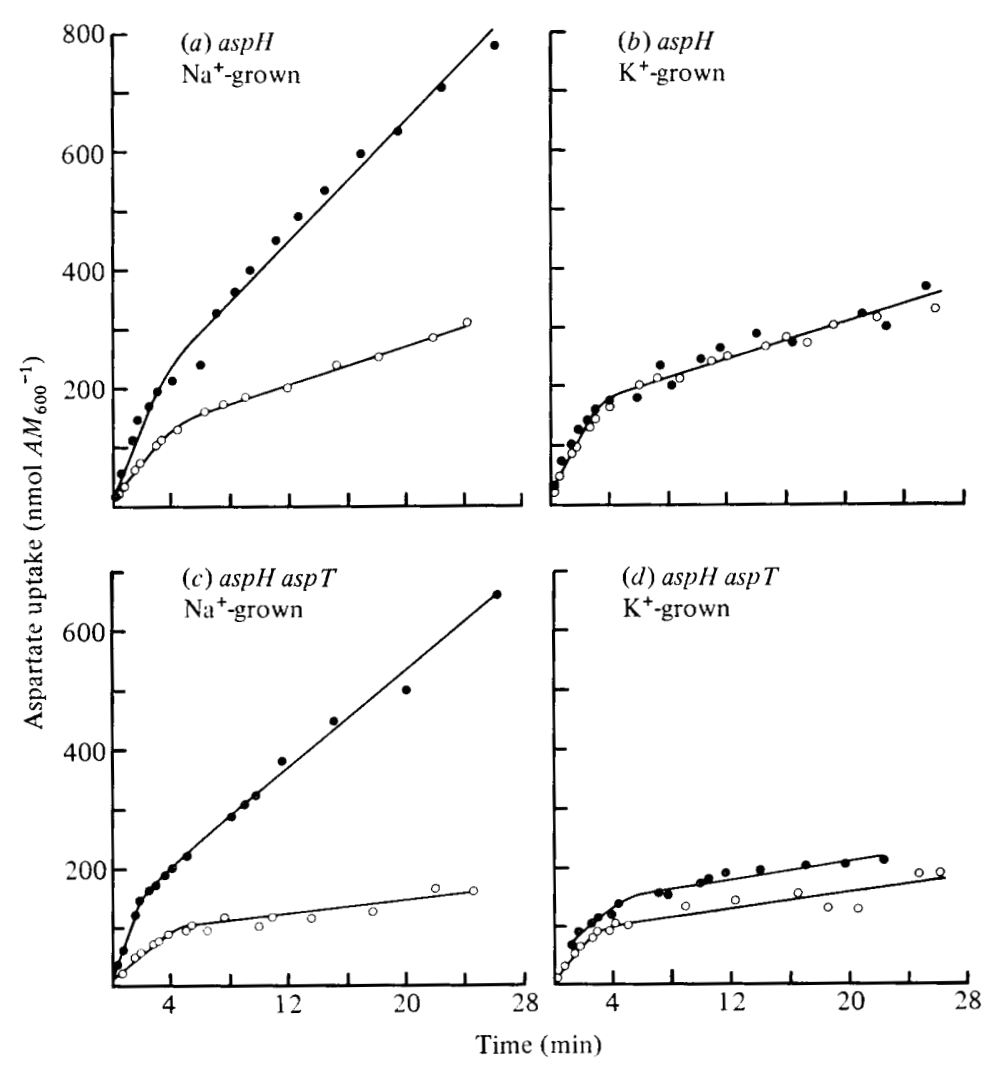

Fig. 3. Uptake of $25 \mathrm{mm-L-aspartate}$ by $(a, b)$ asp $H$ strain 61501 and $(c, d)$ asp $H$ asp $T$ strain 61507. The cells were grown in $\mathrm{S} 6+25 \mathrm{mM}$ sodium or potassium aspartate to $A_{600}=0.1(61507)$ or 0.25 (61501), centrifuged, washed and resuspended in warm $\left(37^{\circ} \mathrm{C}\right) \mathrm{S} 6$. The uptake of sodium and potassium $(\bigcirc) \mathrm{L}$-aspartate $\left(0 \cdot 1 \mu \mathrm{Ci} \mu \mathrm{mol}^{-1}\right)$ was measured as described in Methods. 


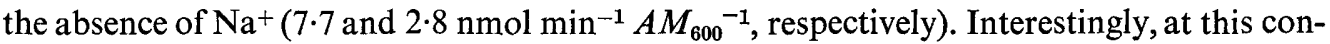
centration of aspartate $(25 \mathrm{mM})$ the aspH aspT strain could still concentrate aspartate in the absence of $\mathrm{Na}^{+}$to an intracellular level of $100 \mathrm{nmol} A M_{600}{ }^{-1}$, i.e. $100 \mathrm{mM}$ if it is assumed that $1 A M_{600}$ represents $1 \mu \mathrm{l}$ intracellular volume. In spite of the high level of intracellular aspartate the strain was unable to grow. This amount of aspartate was not due to nonspecific binding because the aspartate uptake was prevented by $2-n$-heptyl-4-hydroxyquinoline- $N$-oxide $(100 \mu \mathrm{M})$, an inhibitor of the electron transport system and thus of active amino acid transport. In the presence of this inhibitor, the uptake was reduced to about $25 \mathrm{nmol} A M_{600}^{-1}$ which would be expected by the equilibration of intracellular and extracellular aspartate. Furthermore, starvation of the cells (absence of carbohydrates in the medium) for about $1 \mathrm{~h}$ before assaying the aspartate uptake also abolished the concentrative uptake of aspartate.

The possibility existed that the radioactivity observed in the cell in the absence of $\mathrm{Na}^{+}$ was due to a radioactive contaminant of the aspartic acid. When a sample of the aspartic acid solution was chromatographed on a thin layer, traces of radioactive impurities were seen. To purify the $\left[{ }^{14} \mathrm{C}\right]$ aspartate, portions were subjected to preparative thin-layer chromatography using MN300 cellulose plates. The purified potassium aspartate showed an

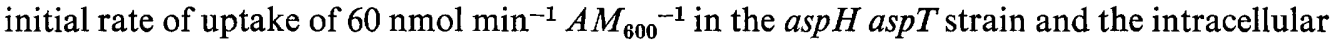
concentration reached $170 \mathrm{nmol} A M_{600}^{-1}$. Thus, the purified material was taken up to an even greater extent than the unpurified commercial aspartate, which indicates that any impurity did not contribute to the observed uptake.

Figure 3 also shows that aspartate was taken up at the same rate, regardless of the presence of $\mathrm{Na}^{+}$or $\mathrm{K}^{+}$, if cells had been pre-grown in the absence of $\mathrm{Na}^{+}$. After the initial rapid uptake was complete, only a very slow continued rate of aspartate uptake was observed even in the presence of $\mathrm{Na}^{+}$. This result shows that the $\mathrm{Na}^{+}$stimulation of growth and metabolism required the adaptation of the cells to $\mathrm{Na}^{+}$.

\section{Attempts to explain the effect of sodium on metabolism}

The requirement for $\mathrm{Na}^{+}$was limited to growth on aspartate as sole carbon source. If the medium contained, as carbon sources, glucose, other carbohydrates or L-malate alone or in addition to aspartate, no $\mathrm{Na}^{+}$requirement was found. The enzymes immediately required for aspartate catabolism, i.e. aspartase, fumarase, malate dehydrogenase and aspartate:2-oxoglutarate aminotransferase, did not exhibit any $\mathrm{Na}^{+}$dependence when assayed in extracts prepared from the aspH aspT strain grown in $25 \mathrm{~mm}$ sodium or potassium aspartate.

In the aspartate-dependent branch of amino acid synthesis, homoserine dehydrogenase is an enzyme known to require $\mathrm{K}^{+}$and to be inhibited by $\mathrm{Na}^{+}$. Conceivably, cells grown with aspartate as sole carbon source could accumulate homoserine or threonine at inhibitory concentrations, and the addition of $\mathrm{Na}^{+}$might reduce this accumulation. To check this possibility, a homoserine-requiring mutant (Hom) was transformed twice by DNA of the aspH aspT strain to produce an aspH aspT Hom triple mutant (strain 61702). This triple mutant grew in S6+sodium aspartate with a doubling time of $1.1 \mathrm{~h}$ only if the medium was supplemented with homoserine $\left(25 \mu \mathrm{g} \mathrm{ml}^{-1}\right)$ or with threonine $\left(25 \mu \mathrm{g} \mathrm{ml}^{-1}\right)+$ methionine $\left(10 \mu \mathrm{g} \mathrm{ml}^{-1}\right)$. In $\mathrm{S} 6+$ potassium aspartate, the doubling time was $3 \mathrm{~h}$ with homoserine and $4.8 \mathrm{~h}$ with threonine + methionine. Since $\mathrm{Na}^{+}$still significantly increased the growth rate of this triple mutant, the accumulation of homoserine or any compound derived from it on the pathways to threonine or methionine cannot be responsible for the inhibition of growth.

Thus, it would seem that either the high concentrations of aspartate or the large amount of ammonia, necessarily produced by cells growing on aspartate as sole carbon source, was responsible for the inhibitory effect that could be counteracted by $\mathrm{Na}^{+}$. Ammonia (or rather $\mathrm{NH}_{4}{ }^{+}$generated from it in the neutral $\mathrm{pH}$ range) could be excreted as such, by co- or countertransport with other ions, or in the form of urea produced in the arginine cycle. 

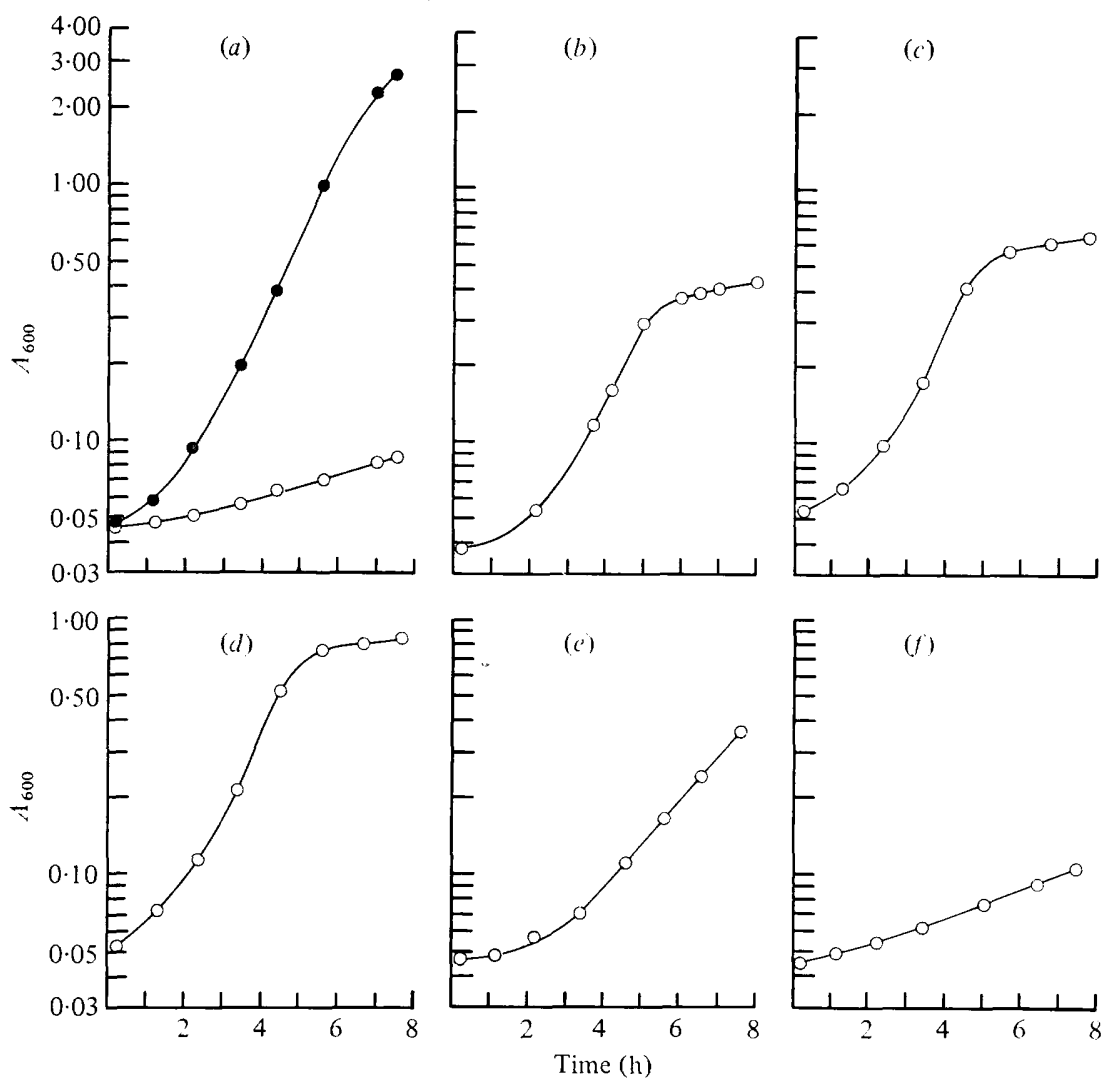

Fig. 4. Growth of aspH aspT strain 61507 in $\mathrm{S} 6+50 \mathrm{~mm}$-potassium L-aspartate and different additions. Cells were pre-grown in $\mathrm{S} 6+50 \mathrm{~mm}$-sodium aspartate, washed and resuspended at $A_{600}=0.05$ in S6+50 mM-potassium aspartate. They were then distributed into flasks containing additions giving the following final concentrations: $(a) 10 \mathrm{~mm}-\mathrm{NaCl}(O)$ or $10 \mathrm{mM}-\mathrm{KCl}(O)$, (b) L-arginine $\left(200 \mu \mathrm{g} \mathrm{ml}^{-1}\right)$, (c) L-ornithine $\left(200 \mu \mathrm{g} \mathrm{ml}^{-1}\right),(d)$ L-proline $\left(200 \mu \mathrm{g} \mathrm{ml}^{-1}\right)$, (e) L-glutamine $\left(500 \mu \mathrm{g} \mathrm{ml}^{-1}\right),(f)$ potassium L-glutamate $\left(1.5 \mathrm{mg} \mathrm{ml}^{-1}\right)$.

In the latter case, addition of arginine or a precursor of it in the arginine cycle might replace $\mathrm{Na}^{+}$, because the urea-producing enzyme arginase is induced by arginine in B. subtilis (Harwood \& Baumberg, 1977). In order to check this possibility and the possible relief from inhibition by aspartate, the ability of the normal amino acids to restore growth in a potassium aspartate medium was determined.

\section{Restoration of growth in potassium aspartate medium by certain amino acids}

The aspH aspT mutant (61507) was grown in S6 +50 mM-sodium aspartate, the cells were sedimented by centrifuging, resuspended in $\mathrm{S} 6+50 \mathrm{mM}$-potassium aspartate and distributed into flasks each containing a different amino acid (final concentration $200 \mu \mathrm{g}$ $\mathrm{ml}^{-1}$ ); all amino acids normally present in proteins were tested, with the exception of L-cysteine. As shown in Fig. 4, arginine, citrulline and ornithine restored growth in the absence of $\mathrm{Na}^{+}$but so did proline; glutamine was less effective and glutamate was ineffective. All other amino acids tested had little or no effect. $N$-Acetyl-L-glutamate or $N$-acetyl-L-ornithine $\left(1 \mathrm{mg} \mathrm{ml} \mathrm{m}^{-1}\right)$ and the potassium salts of acetate, succinate, 2-oxoglutarate or citrate (all $10 \mathrm{~mm}$ ) were also ineffective. L-Cysteine $\left(50 \mu \mathrm{g} \mathrm{ml}^{-1}\right)$, DLhomocysteine $\left(100 \mu \mathrm{g} \mathrm{ml}^{-1}\right)$ and DL-homoserine $\left(200 \mu \mathrm{g} \mathrm{ml}^{-1}\right)$ inhibited growth. The direct proline precursor $\mathrm{L}-\Delta^{\mathbf{1}}$-pyrroline-5-carboxylate $\left(100 \mu \mathrm{g} \mathrm{ml}^{-1}\right)$ also restored growth. The compounds capable of restoring growth are metabolically related as shown in Fig. 5. The 


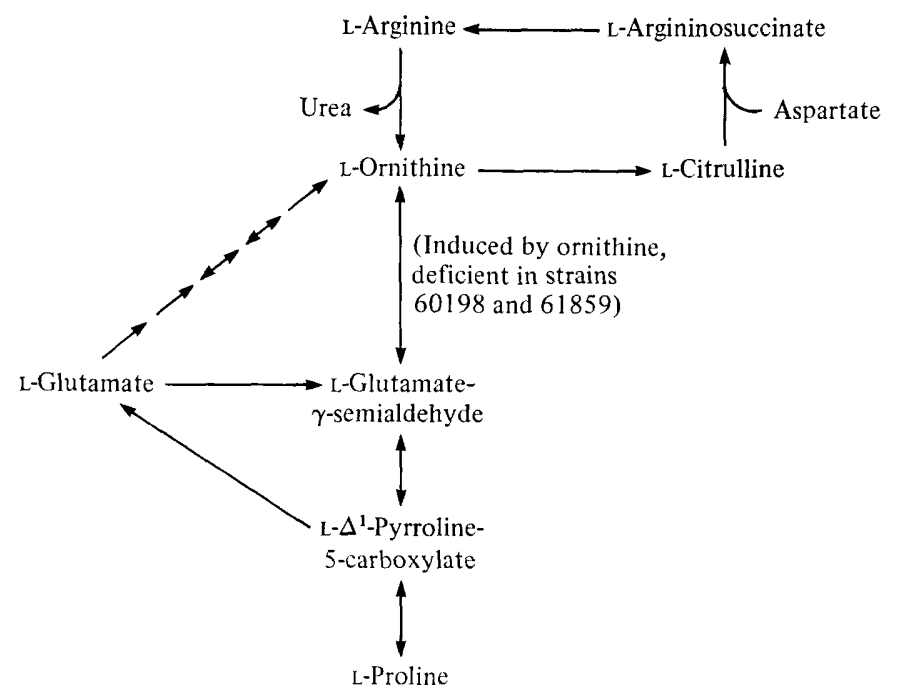

Fig. 5. Metabolic relationship of compounds that allow rapid growth of aspH aspT strain 61507 in $\mathrm{S} 6+50 \mathrm{~mm}$-potassium L-aspartate.

question now raised was whether the compound actually required for rapid growth on potassium aspartate was a member of the arginine cycle or whether it was proline. Since a proline auxotroph (60961) could also grow on media supplemented with ornithine whereas an ornithine auxotroph (60019) could grow on ornithine but not on proline, ornithine apparently can be converted to proline but not the reverse. This suggested that compounds capable of supporting rapid growth in potassium aspartate did so by being converted to proline. This was confirmed by use of a mutant $(\mathrm{Ord})$ which had been isolated in our laboratory as being unable to use ornithine as sole nitrogen source. The Ord mutation creates a block in the ornithine-oxo-acid aminotransferase which converts ornithine to glutamate semialdehyde (Table 2). A triple mutant aspH aspT Ord (strain 61859) was isolated by its ability to grow on plates containing glutamate, as sole nitrogen source, but not on those containing ornithine. Table 2 shows that ornithine-oxo-acid aminotransferase was induced by growth of the aspH aspT strain (61507) in the presence of ornithine. But the triple mutant (61859) showed no or only little activity of this enzyme, regardless of whether it was grown in the presence or absence of ornithine. The aspH aspT Ord strain could not grow rapidly in potassium aspartate supplemented $\left(1 \mathrm{mg} \mathrm{ml} \mathrm{m}^{-1}\right)$ with arginine, citrulline or ornithine, but it grew well in the presence of proline or pyrrolinecarboxylate; in sodium aspartate this triple mutant grew as well (doubling time $1.0 \mathrm{~h}$ ) as the aspH aspT strain (Fig. 6).

\section{Amino acid composition of cells grown under different conditions}

The major enzyme leading from glutamate to glutamate semialdehyde (L-glutamate- $\gamma$ semialdehyde dehydrogenase) has never been demonstrated (Adams, 1970), and we were also unable to do so. Therefore, we could not determine whether this enzyme might possibly require activation by $\mathrm{Na}^{+}$. The pyrroline-5-carboxylate reductase, the other enzyme needed for proline synthesis, was not $\mathrm{Na}^{+}$-dependent.

To see whether the production of proline might be deficient in cells growing on potassium aspartate but not in those growing on sodium aspartate as sole carbon source or whether some other differences in amino acids pools were apparent, extracts of cells grown in these media and also of cells grown in the presence of proline were prepared by rapid filtration 
Table 2. Activity of ornithine-oxo-acid aminotransferase

Cells were grown in S6 containing $50 \mathrm{~mm}$-potassium aspartate (Asp) with or without $10 \mathrm{~mm}-\mathrm{NaCl}$ and with or without $100 \mu \mathrm{g}$ L-ornithine (Orn) $\mathrm{ml}^{-1}$. Extracts were prepared and assayed as described in Methods. Specific activity is expressed as pmol $\min ^{-1}$ (mg protein) $)^{-1}$.

$\begin{array}{llll}\text { Strain } & \overbrace{\begin{array}{c}\text { Cells grown in } \\ \text { S6 (Na) + Asp }\end{array}}^{\text {Cells grown in }} \begin{array}{c}\text { S6 (K) + Asp } \\ \text { aspH aspT }\end{array} & \overbrace{- \text { Orn }+ \text { Orn }}^{\text {Specific activity }} & + \text { Orn } \\ \text { aspH aspT Ord } & 2.83 & 85.1 & 192 \cdot 1 \\ & 2.47 & 1.47 & \text { No growth }\end{array}$

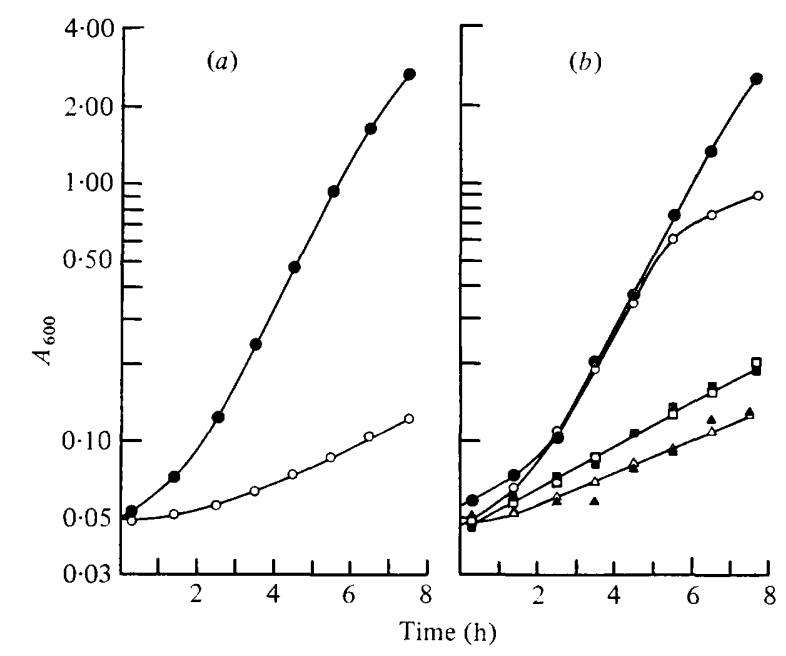

Fig. 6. Growth of aspH asp 1 Ord strain 61859 in $\mathrm{S} 6+50 \mathrm{~mm}$-potassium aspartate in the presence of (a) $10 \mathrm{~mm}-\mathrm{NaCl}(\bullet)$ or $10 \mathrm{~mm}-\mathrm{KCl}(\bigcirc),(b)$ proline $(\bigcirc, \bullet)$, ornithine $(\square, \boldsymbol{\square})$ or arginine $(\triangle, \mathbf{\Delta})$ at $200 \mu \mathrm{g} \mathrm{ml}^{-1}$ (open symbols) or $1 \mathrm{mg} \mathrm{ml}^{-1}$ (closed symbols).

and formic acid extraction. The amounts of amino acids found are shown in Table 3 . First, it is apparent that all cells contained large amounts of aspartate. Although the concentrations of the other amino acids differed to some extent in cells grown in different media, only for citrulline and proline were differences of more than a factor of two observed. As would be expected, the cells grown in the presence of proline contained more than ten times the concentration of proline than did those grown without extracellular proline. But no significant difference was observed in the concentration of proline in cells grown with sodium or potassium aspartate. Thus, the ability of proline to support growth must be related either to some aspect of its transport into the cells or to its intracellular concentration. The accumulation of citrulline in cells growing with potassium aspartate indicated that argininosuccinate synthetase is (always or only in the absence of $\mathrm{Na}^{+}$) rate-limiting. Thus, aspartate or $\mathrm{NH}_{4}{ }^{+}$metabolism via the arginine cycle and the removal of nitrogen by urea production appears to be rather inefficient in $B$. subtilis. Apparently, the accumulation of citrulline is avoided only in rapidly growing cells where arginine is rapidly utilized for protein synthesis. In any case, these processes are not relevant to this paper. 
Table 3. Amino acid composition of aspH aspT strain 61507

\begin{tabular}{|c|c|c|c|c|}
\hline \multirow[b]{3}{*}{ Amino acid } & \multicolumn{4}{|c|}{ Amino acid content $\left(\mathrm{nmol} A_{600}{ }^{-1}\right)$} \\
\hline & \multicolumn{4}{|c|}{ Cells grown with: } \\
\hline & $\mathrm{K}^{+}$ & $\mathrm{K}^{+}+$proline & $\mathrm{Na}^{+}$ & $\mathrm{Na}^{+}+$proline \\
\hline Alanine & $8 \cdot 0$ & $7 \cdot 0$ & $6 \cdot 5$ & $5 \cdot 7$ \\
\hline$\alpha$-Aminoadipate & ND & $<0.1$ & $2 \cdot 2$ & $3 \cdot 3$ \\
\hline$\alpha$-Aminobutyrate & 0.5 & $<0.1$ & $0 \cdot 2$ & $0 \cdot 3$ \\
\hline Aspartate & $206 \cdot 3$ & $274 \cdot 1$ & $201 \cdot 3$ & $163 \cdot 1$ \\
\hline Arginine & $<0 \cdot 1$ & $<0.1$ & $<0 \cdot 1$ & $<0 \cdot 1$ \\
\hline Citrulline & $23 \cdot 3$ & $8 \cdot 9$ & $11 \cdot 2$ & $8 \cdot 4$ \\
\hline Cystine & 8.8 & $8 \cdot 7$ & 8.8 & $7 \cdot 5$ \\
\hline Glutamate & $490 \cdot 4$ & $503 \cdot 0$ & $313 \cdot 0$ & $276 \cdot 9$ \\
\hline Glutamine and homoserine & $42 \cdot 7$ & $24 \cdot 7$ & $23 \cdot 2$ & $20 \cdot 1$ \\
\hline Glycine & $2 \cdot 1$ & $1 \cdot 7$ & 2.9 & $2 \cdot 3$ \\
\hline Histidine & 0.8 & ND & $<0 \cdot 1$ & $<0 \cdot 1$ \\
\hline Isoleucine and leucine & $3 \cdot 7$ & $5 \cdot 8$ & $6 \cdot 0$ & $5 \cdot 5$ \\
\hline Lysine & $1 \cdot 4$ & $0 \cdot 8$ & $1 \cdot 3$ & $1 \cdot 6$ \\
\hline Methionine & $2 \cdot 3$ & $2 \cdot 2$ & $2 \cdot 2$ & $2 \cdot 2$ \\
\hline Ornithine & $1 \cdot 4$ & $2 \cdot 5$ & $2 \cdot 1$ & $1 \cdot 9$ \\
\hline Phenylalanine & 0.9 & $<0.1$ & ND & ND \\
\hline Proline & $6 \cdot 2$ & $77 \cdot 4$ & $5 \cdot 4$ & $43 \cdot 4$ \\
\hline Serine & $7 \cdot 6$ & $5 \cdot 6$ & $4 \cdot 6$ & $4 \cdot 1$ \\
\hline Threonine & $2 \cdot 2$ & $2 \cdot 8$ & $3 \cdot 4$ & $3 \cdot 1$ \\
\hline Tyrosine & 0.4 & $<0.1$ & ND & ND \\
\hline Tryptophan & $<0.1$ & $<0 \cdot 1$ & $<0.1$ & $<0 \cdot 1$ \\
\hline Valine & 3.9 & $7 \cdot 0$ & 3.9 & $3 \cdot 7$ \\
\hline Unknown 1 & $3 \cdot 2$ & $3 \cdot 6$ & $3 \cdot 0$ & $2 \cdot 6$ \\
\hline Unknown 2 & ND & $1 \cdot 1$ & $2 \cdot 3$ & $2 \cdot 0$ \\
\hline
\end{tabular}

\section{DISCUSSION}

asp $H$ strains of $B$. subtilis, producing aspartate constitutively, grow on aspartate as sole carbon source much faster if the medium contains $\mathrm{Na}^{+}$than if it contains only $\mathrm{K}^{+}$; this effect is specific to $\mathrm{Na}^{+}$(Iijima et al., 1977). At high concentrations of aspartate the growth rate is not affected by the presence of the high affinity aspartate transport system since that is saturated at about $200 \mu \mathrm{M}$-aspartate. The low affinity aspartate transport system also seems to involve active transport because the inside concentration of aspartate is several-fold higher than the outside concentration even in the absence of $\mathrm{Na}^{+}$; in an aspH asp $T$ mutant, lacking the high affinity aspartate transport system, this accumulation is prevented by starvation or by inhibition of the electron transport system. This observation and the fact that the initial rates of aspartate uptake show much less $\mathrm{Na}^{+}$dependence than the rates of growth (compare Figs $1 b$ and $2 b$ ) demonstrate that the much higher growth rates on aspartate observed in the presence of $\mathrm{Na}^{+}$do not result from a $\mathrm{Na}^{+}$-stimulated increase of aspartate transport but from an effect on cell metabolism. (There was some increase in the initial rate of aspartate uptake if the medium contained $\mathrm{Na}^{+}$. But it is well known that transport and metabolism cannot be strictly separated in whole cells. Although we have tried to optimize this separation by rapid sampling after aspartate addition, it is not clear whether the observed increase in aspartate uptake is due to a $\mathrm{Na}^{+}$effect on aspartate transport or whether it also results from the $\mathrm{Na}^{+}$effect on metabolism. However this may be, it does not affect our major conclusion.)

Since $\mathrm{Na}^{+}$does not affect growth on other carbon sources, and since all initial enzymes metabolizing aspartate as carbon source are not stimulated by $\mathrm{Na}^{+}$, the slow growth without $\mathrm{Na}^{+}$must be caused by the presence of high intracellular concentrations of aspartate, or of $\mathrm{NH}_{4}{ }^{+}$which is immediately formed from the $\mathrm{NH}_{3}$ liberated from aspartate via 
aspartase. The possibility that $\mathrm{Na}^{+}$stimulates growth by inhibiting the $\mathrm{K}^{+}$-dependent homoserine dehydrogenase has been excluded. Conceivably, the inhibition of some other enzyme by aspartate or $\mathrm{NH}_{4}{ }^{+}$could be counteracted by $\mathrm{Na}^{+}$. But it is also possible that $\mathrm{Na}^{+}$allows the rapid export of (inhibitory) $\mathrm{NH}_{4}{ }^{+}$by countertransport; in this case $\mathrm{Na}^{+}$ itself would have to be exported by a $\mathrm{Na}^{+}$export system, whose existence has been indirectly demonstrated in several bacteria (Silver, 1978). The $\mathrm{Na}^{+}$stimulation effect of $B$. subtilis growth on aspartate (i.e. possibly the $\mathrm{Na}^{+}$export mechanism) is inducible by prior growth in the presence of $\mathrm{Na}^{+}$.

Growth in potassium aspartate can also be greatly enhanced by arginine, citrulline, ornithine, pyrroline-5-carboxylate or proline. Proline (or pyrroline-carboxylate) is the compound actually needed; all other compounds can be converted into it. An Ord mutant, deficient in ornithine-oxo-acid aminotransferase, can still grow rapidly in potassium aspartate plus proline (or pyrroline-carboxylate) but not with arginine, citrulline or ornithine. Since this mutant can grow on glucose or other carbon sources without addition of ornithine or arginine it is apparent that ornithine-oxo-acid aminotransferase differs from acetylornithine aminotransferase (which is needed for the synthesis of $N$-acetylornithine and thus ornithine from glutamate). This is also supported by the fact that ornithine-oxo-acid aminotransferase is inducible by ornithine (or arginine) as was previously shown by Harwood \& Baumberg (1977) whereas the acetylornithine aminotransferase is repressed by arginine (Vogel \& Vogel, 1963).

It is not clear why proline allows good growth in the presence of potassium aspartate whereas other amino acids do not. Conceivably, aspartate might inhibit one of the steps in the formation of proline from glutamate; the first enzyme of this pathway (glutamate- $\gamma$ semialdehyde dehydrogenase) has still not been detected in any organism (Adams, 1970) so that its possible inhibition by aspartate (as an analogue of glutamate) or the possible counteraction of such inhibition by $\mathrm{Na}^{+}$could not be measured. However, B. subtilis is able to produce some proline in the absence of $\mathrm{Na}^{+}$because we have found the same intracellular concentration of proline in cells grown in either sodium or potassium aspartate. Thus, it is rather the more than 10-fold higher concentration of proline found in cells grown in the presence of proline, which allows growth on potassium aspartate. Possibly, proline counteracts the inhibition of some metabolic reaction by aspartate or $\mathrm{NH}_{4}^{+}$, such as the proline-activating enzyme. Alternatively, proline might activate some enzyme needed for growth on potassium aspartate. But it is also possible that proline specifically allows the more rapid export of inhibitory $\mathrm{NH}_{4}{ }^{+}$either by countertransport or, following its own active import, by symport.

\section{R EFERENCES}

Adams, E. (1970). Metabolism of proline and of hydroxyproline. In International Review of Connective Tissue Research, vol. 5, pp. 1-91. Edited by D. A. Hall \& D. S. Jackson. New York \& London: Academic Press.

ANAGNostopoulos, C. \& Spizizen, J. (1961). Requirements for transformation in Bacillus subtilis. Journal of Bacteriology 81, 741-746.

Frank, L. \& Hopkins, I. (1969). Sodiumstimulated transport of L-glutamate in Escherichia coli. Journal of Bacteriology 100, 329-336.

Halpern, Y.S., Barash, H., Dover, S. \& Druck, K. (1973). Sodium and potassium requirements for active transport of glutamate by Escherichia coli K-12. Journal of Bacteriology 114, 53-58.

HaRwood, C. R. \& Baumberg, S. (1977). Arginine hydroxamate-resistant mutant of Bacillus subtilis with altered control of arginine metabolism. Journal of General Microbiology 100, 177-188.

Hirata, H., Kosmukos, F. C. \& Brodie, A. F. (1974). Active transport of proline in membrane preparations from Mycobacterium phlei. Journal of Biological Chemistry 249, 6965-6970.

Inima, T., DiesterhafT, M. D. \& Freese, E. (1977). Sodium effect of growth on aspartate and genetic analysis of a Bacillus subtilis mutant with high aspartase activity. Journal of Bacteriology 129, 1440-1447.

Miner, K. M. \& Frank, L. (1974). Sodiumstimulated glutamate transport in osmotically shocked cells and membrane vesicles of Escherichia coli. Journal of Bacteriology 117, 1093-1098.

MYers, W. F. \& HuANG, K.-Y. (1966). Separation 
of intermediates of the citric acid cycle and other related compounds by thin-layer chromatography. Analytical Biochemistry 17, 210-213.

Saito, H. \& MiURA, K. (1963). Preparation of transforming deoxyribonucleic acid by phenol treatment. Biochimica et biophysica acta 72, 619-629.

SILVER, S. (1978). Transport of cations and anions. In Bacterial 1ransport, pp. 221-324. Edited by B. P. Rosen. New York: Marcel Dekker.

Tsuchiya, T., Hasan, S. \& Raven, J. (1977). Glutamate transport driven by an electrochemical gradient of sodium ions in Escherichia coli. Journal of Bacteriology 131, 848-853.

VoGel, H. J. \& DAVIS, B. D. (1952). Glutamic- $\gamma$ semialdehyde and $\Delta^{1}$-pyrroline 5-carboxylic acid, intermediates in the biosynthesis of proline. Journal of the American Chemical Society 74, 109-112.

VoGel, R. \& KoPAC, M. J. (1960). Some properties of ornithine S-transaminase from Neurospora. Biochimica et biophysica acta 37, 539-540.

Vogel, R. H. \& VoGel, H. J. (1963). Acetylated intermediates of arginine synthesis in Bacillus subtilis. Biochimica et biophysica acta 69, 174-176.

Whiteman, P. A., Injma, T., Diesterhaft, M. D. \& FreEse, E. (1978). Evidence for a low affinity but high velocity aspartate transport system needed for rapid growth of Bacillus subtilis on aspartate as sole carbon source. Journal of General Microbiology 107, 297-307. 